Portland State University

PDXScholar

Environmental Science and Management

Professional Master's Project Reports

\title{
Informing Oregon's Marine Protected Area (MPA) Baseline Past and Present Tribal Uses of Marine Resources
}

Sabra Marie TallChief Comet

Portland State University

Follow this and additional works at: https://pdxscholar.library.pdx.edu/mem_gradprojects

Part of the Environmental Health and Protection Commons, Environmental Monitoring Commons, and the Water Resource Management Commons

Let us know how access to this document benefits you.

\section{Recommended Citation}

Comet, Sabra Marie TallChief, "Informing Oregon's Marine Protected Area (MPA) Baseline Past and Present Tribal Uses of Marine Resources" (2017). Environmental Science and Management Professional Master's Project Reports. 27.

https://pdxscholar.library.pdx.edu/mem_gradprojects/27

https://doi.org/10.15760/mem.9

This Project is brought to you for free and open access. It has been accepted for inclusion in Environmental Science and Management Professional Master's Project Reports by an authorized administrator of PDXScholar. Please contact us if we can make this document more accessible: pdxscholar@pdx.edu. 


\title{
Informing Oregon's Marine Protected Area (MPA) Baseline Past and Present Tribal Uses of Marine Resources
}

by

\author{
Sabra Marie TallChief Comet
}

A thesis submitted in partial fulfillment of the requirements for the degree of

Master of Environmental Management

Thesis Committee:

Dr. Max Nielsen-Pincus

Dr. Elise Granek

Dr. Thomas Swearingen

Portland State University

2017 


\section{Table of Contents}

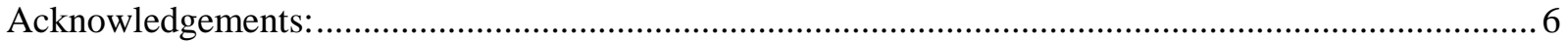

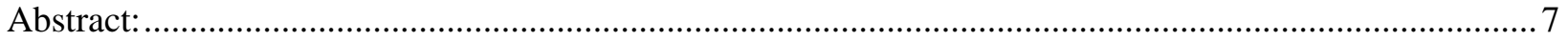

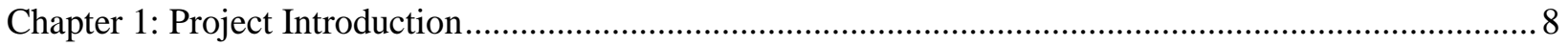

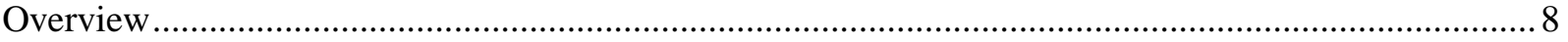

Study Area

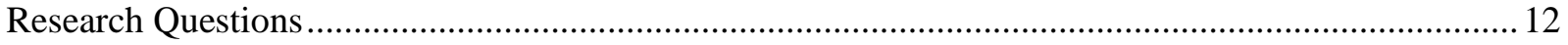

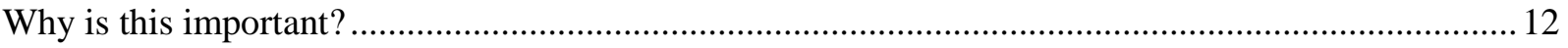

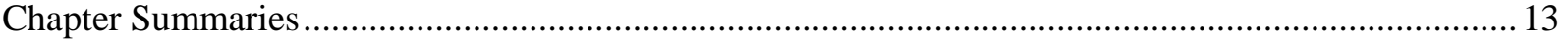

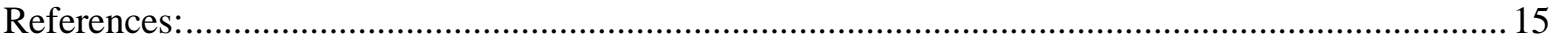

Chapter 2: Tribal Member Interview Narratives of Coastal Species Use .............................................. 17

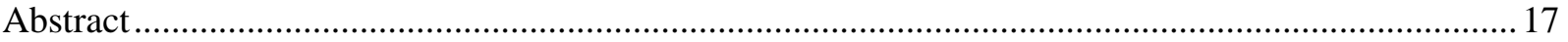

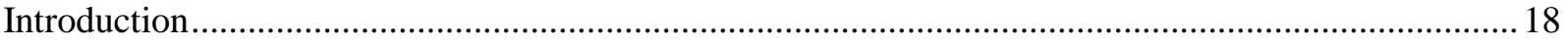

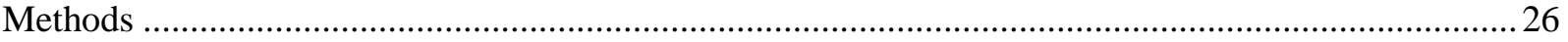

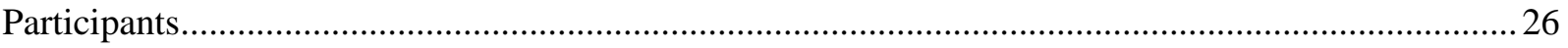

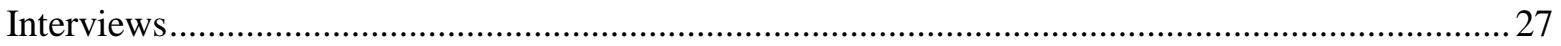

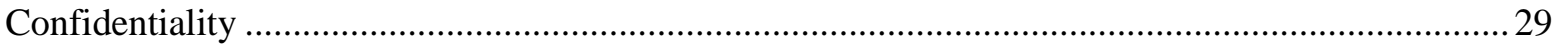

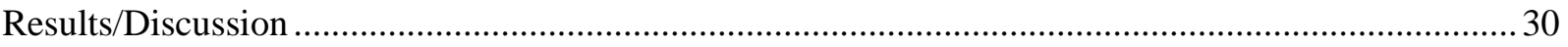

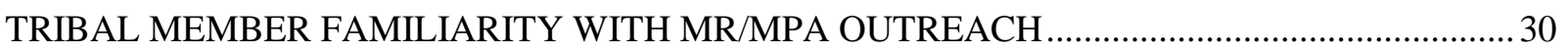

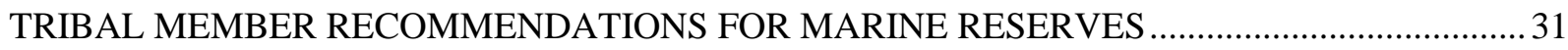

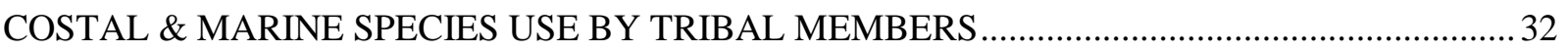

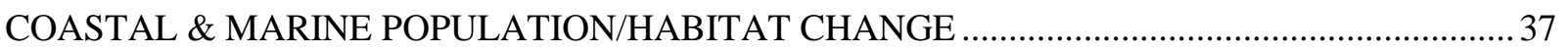

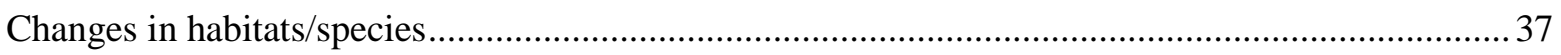

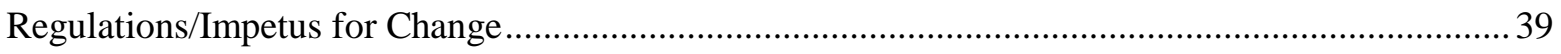

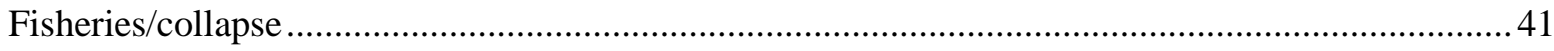

TRIBAL MEMBER EXPERIENCES WITH ENFORCEMENT OF “TAKE” REGULATIONS ........43

Oregon Fish and Wildlife Outreach and Legal Limitations............................................................ 43

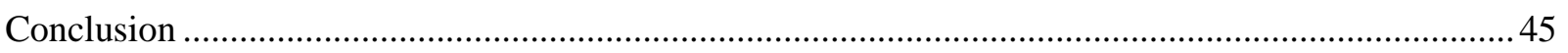

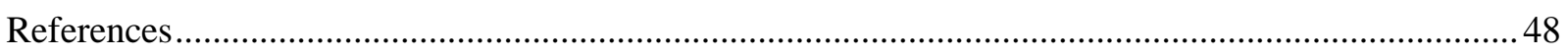

Chapter 3: Spatial Distribution of Tribal Marine and Coastal Species on the Oregon Coast .....................50

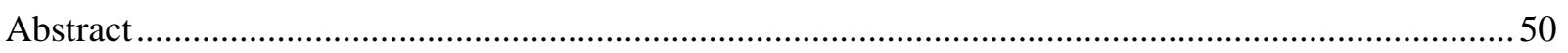

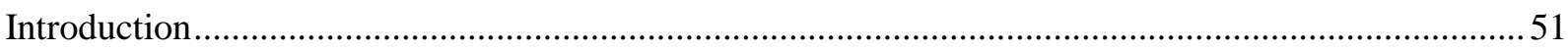

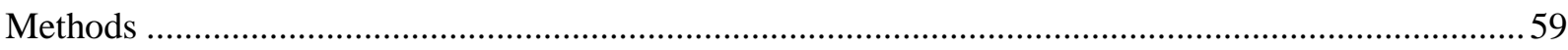

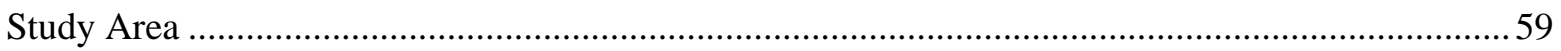

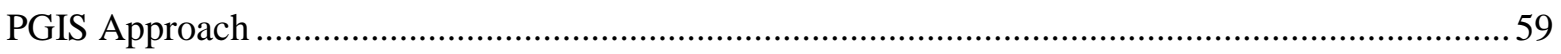




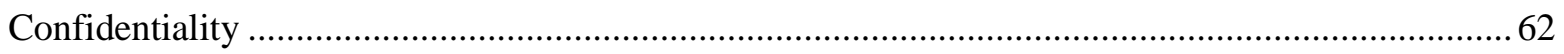

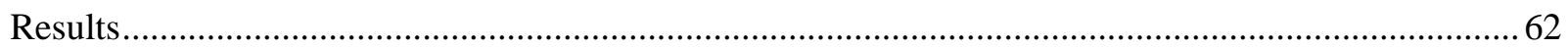

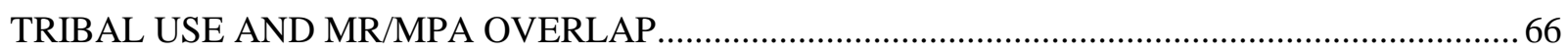

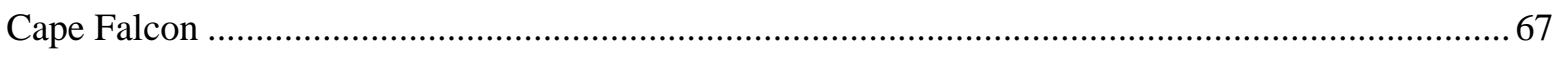

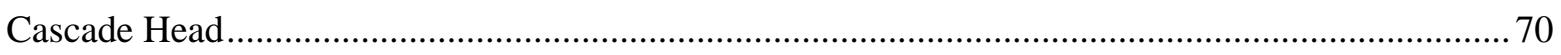

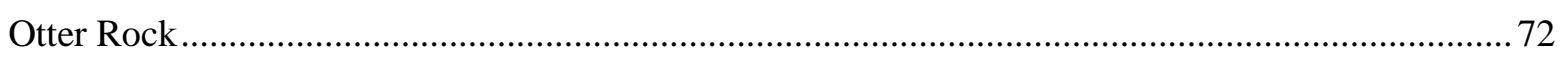

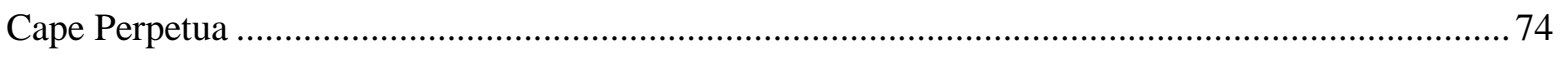

HOTSPOTS OF TRIBAL USE OF MARINE AND COASTAL SPECIES ..................................... 78

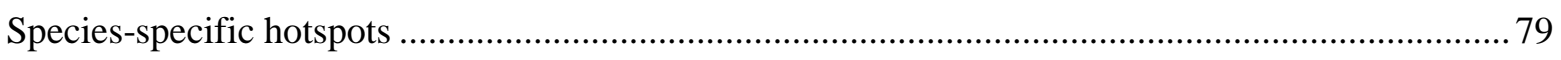

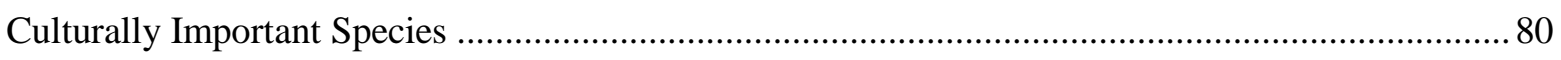

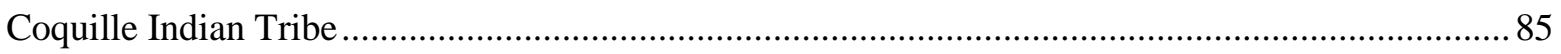

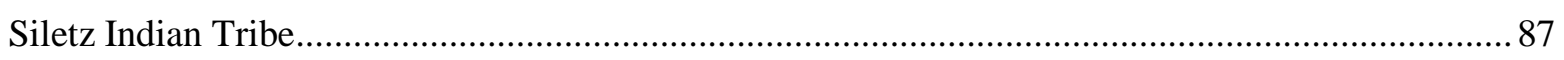

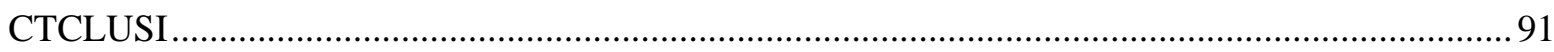

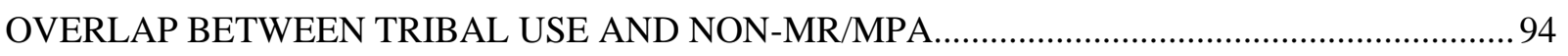

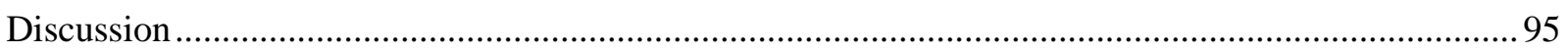

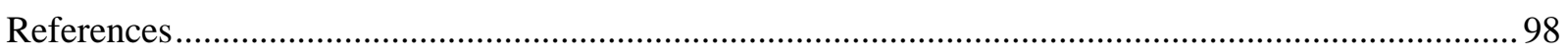

Chapter 4: Techniques for natural resource practitioners to productively engage with tribes.................. 101

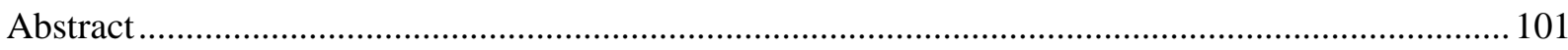

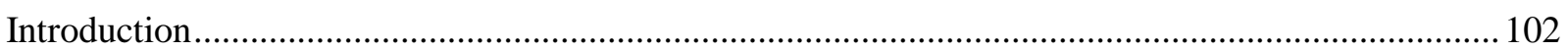

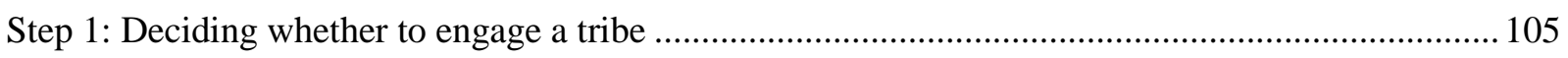

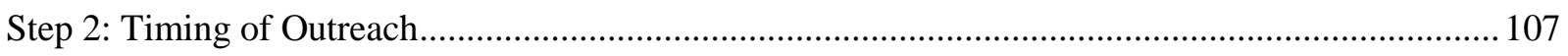

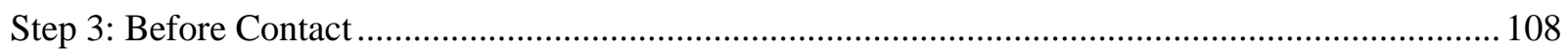

Cultural Sensitivity During Tribal Engagement ...................................................................... 109

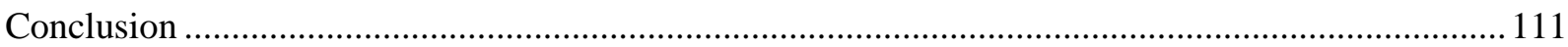

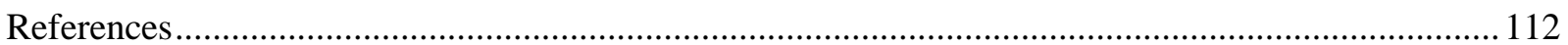

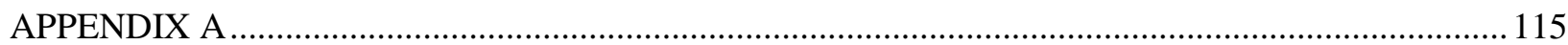

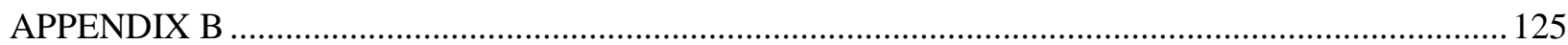

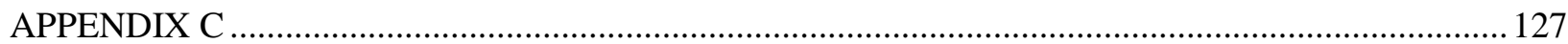

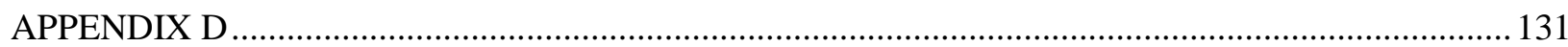

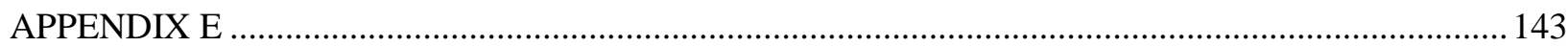

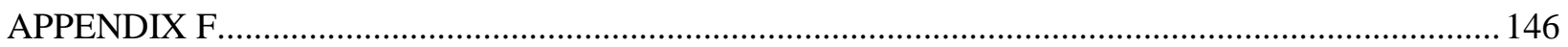

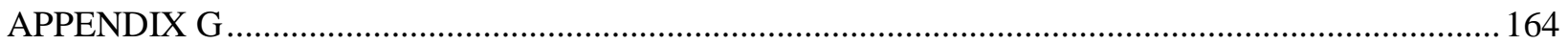




\section{Table of Figures}

\section{Chapter 2}

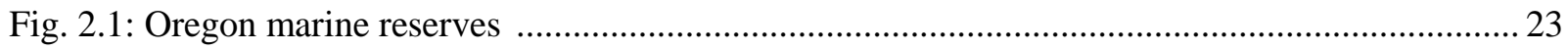

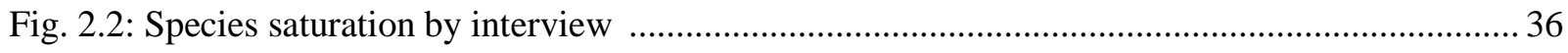

\section{Chapter 3}

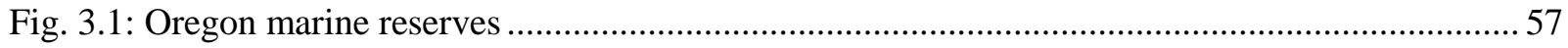

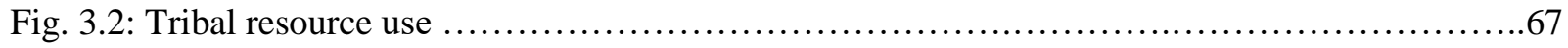

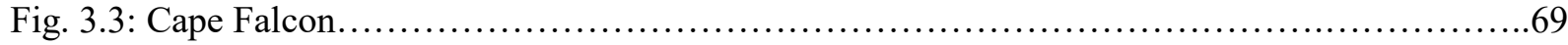

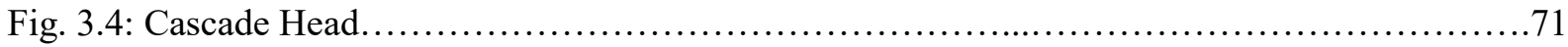

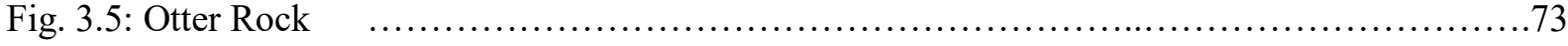

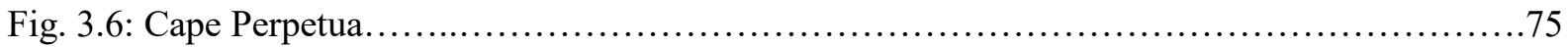

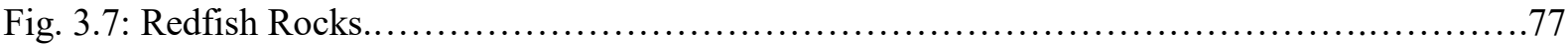

Fig. 3.8: All tribal marine/coastal species use.............................................79

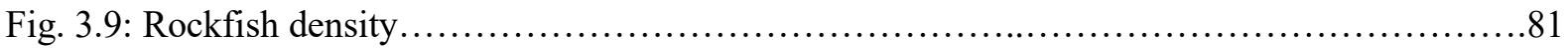

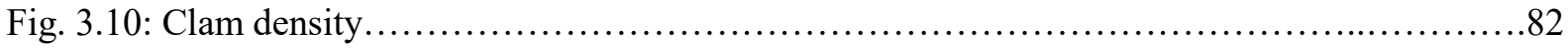

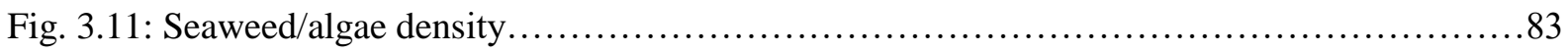

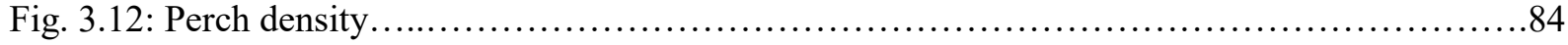

Fig. 3.13: Coquille tribe species use bar chart............................................. 86

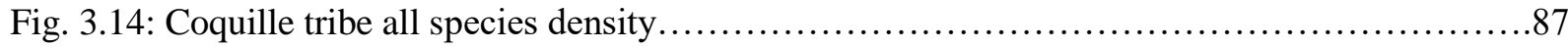

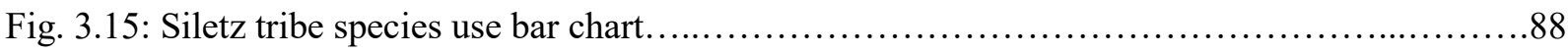

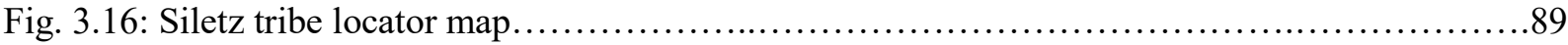

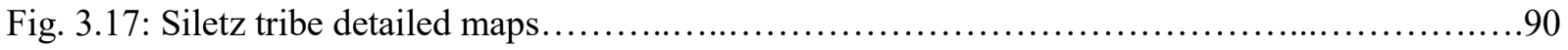

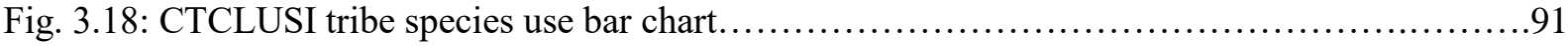

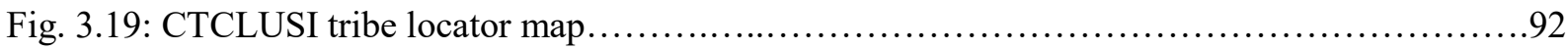

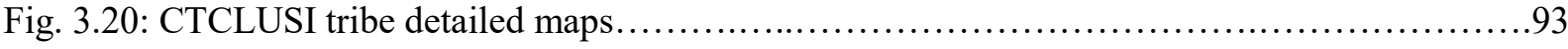

\section{Chapter 4}

Fig. 4.1: Infographic

\section{Appendix F}

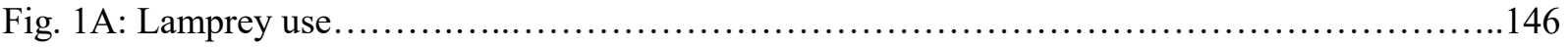

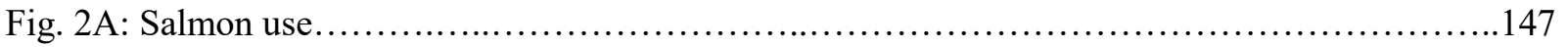

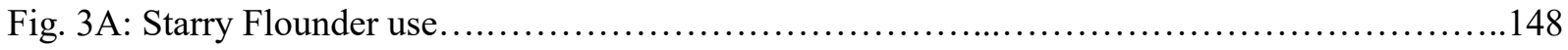


Fig. 4A: Bass use.................................................................. 149

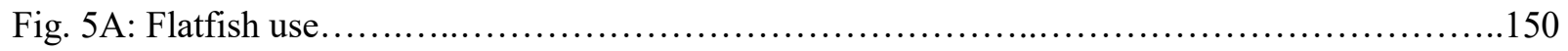

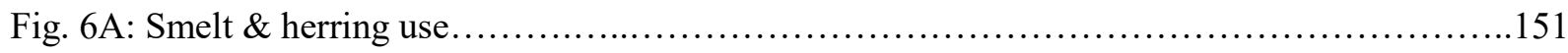

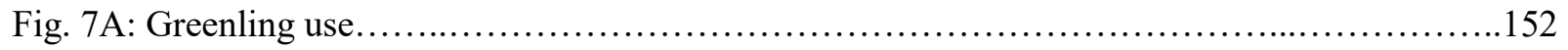

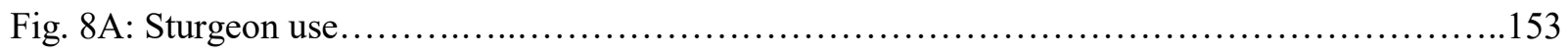

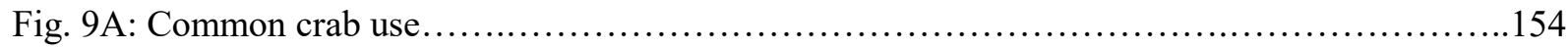

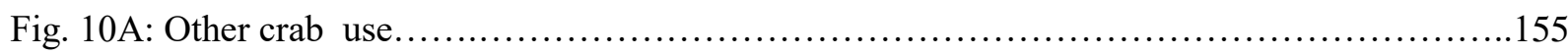

Fig. 11A: Olivella use............................................................... 155

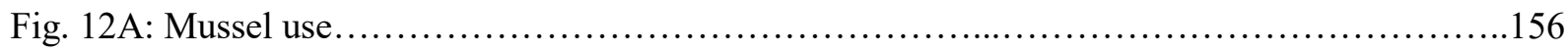

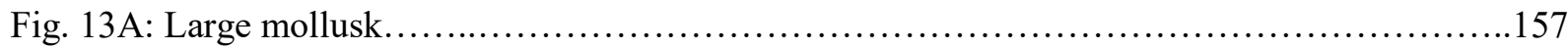

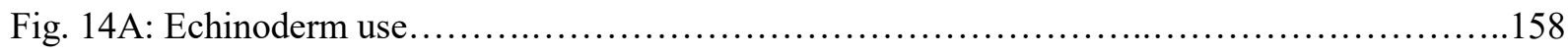

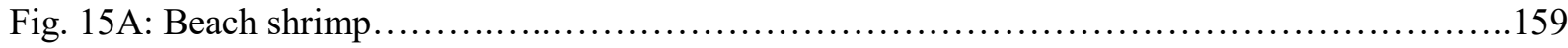

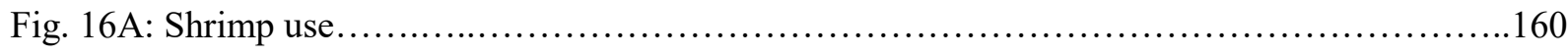

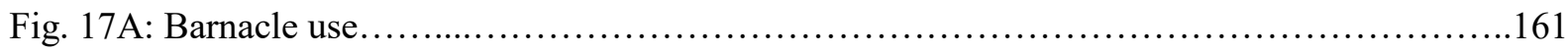

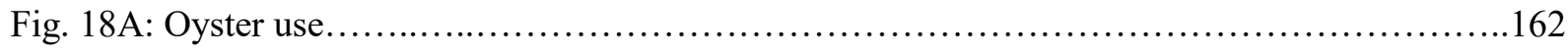

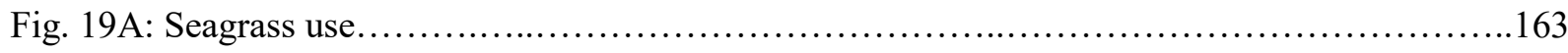

\section{Table of Tables}

\section{Chapter 1}

Table 1.1: Legislation for creation/implementation of Oregon MR/MPAs

\section{Chapter 2}

Table 2.1: Frequency of species groups

\section{Chapter 3}

Table 3.1: Geographic region of ancestral bands/tribes of interview participants .66

\section{Chapter 4}

Table 4.1: Categories of tribes

\section{Appendix B}

Table 1A: Regional and alternate species names

$.126-127$

\section{Appendix C}

Table 2A: Frequency of species use. 128-132 


\section{Acknowledgements:}

I would like to thank the following, without whom this project would not have been possible: my committee, Dr. Max Nielsen Pincus (Portland State University), Dr. Elise Granek (Portland State University), and Dr. Tommy Swearingen (Oregon Fish and Wildlife Department); Oregon Sea Grant for funding the project; the staff and members of the participating tribes; Samantha Hamlin, Barbara Moreland, and Cody Evers (Portland State University) for re-training in GIS; both graduate labs, my MEM cohort, and all the others who have given input since this project's infancy. 


\section{Abstract:}

Oregon implemented a series of marine reserves from 2012 through the beginning of 2016 that will be evaluated in 2023. As part of that evaluation, several studies are focusing on the impact of the reserves on coastal communities. This project focused on tribal members with ancestral territory on the Oregon coast. Tribal members from three tribes, the Confederated Tribes of Siletz Indians, the Coquille Indian Tribe, and the Confederated Tribes of Coos, Lower Umpqua, and Siuslaw Indians were interviewed for this project. The interviews centered around two themes: 1) past and present use of marine and coastal species, and 2) experiences and opinions about the implementation and policies of Oregon's marine reserves. A mapping exercise in which tribal members marked where they gathered species was performed concurrently with the interviews. Shared patterns in the interview narratives around changes in plant/animal populations, habitats, and land uses are the focus on Chapter 2. Spatial information from the mapping exercise is the focus of Chapter 3. Chapter 4 briefly introduces techniques for efficiently engaging with tribes on resource management projects, using this project as the example application for the techniques. Over 150 species were reported by 28 participants in 23 interviews, and the areas marked during the mapping exercise covered over 12,000 square kilometers. Several trends were corroborated across interviews, including the timing of two smelt populations, and the crash and slow recovery of the Starry Flounder. There was traditional/subsistence use reported in areas overlapping four of the five marine reserves in Oregon, although some of the activity had stopped well before the implementation of the reserves. The majority of participants were in favor of the existence of marine reserves, but had a variety of suggestions for changes to the implementation and policy. 
This document contains culturally sensitive indigenous knowledge that is not available for full public access. If you wish access to the full article please contact the primary author at ttallcomet@gmail.com to discuss appropriate usage of the data. 